\title{
Yield and Quality Features of Buckwheat-Soybean Mixtures in Organic Agricultural Conditions
}

\author{
Mustafa Sürmen*, Emre Kara
}

Department of Field Crops, Faculty of Agriculture, Adnan Menderes University, 09970 Koçarll/Aydın Türkiye

\section{A R T I C LE I N F O}

\#27-29 Eylül 2017'de Bayburt / Türkiye'de düzenlenen ' 1 st International Organic Agriculture and Biodiversity' kongresinde özet olarak sunulmuştur.

\section{Research Articles}

Received 12 September 2017 Accepted 30 November 2017

\section{Keywords:}

Buckwheat

Soybean

Mixture

Crude protein

$\mathrm{ADF}$

$\mathrm{NDF}$

"Corresponding Author:

E-mail: mustafa.surmen@adu.edu.tr

\section{A B S T R A C T}

This study was carried out during the summer of 2014 to determine alternative quality forage sources that could be grown in the Aydin ecological conditions. In the study, effects of 3 different mixtures and 2 pure species (100\% Buckwheat, 25\% Buckwheat -75\% Soybean, 50\% Buckwheat $-50 \%$ Soybean, 75\% Buckwheat - 25\% Soybean, 100\% Soybean) and 2 different harvesting times (50\%-100\% flowering/buckwheat) on yield and quality characteristics were investigated. According to measurements, the highest average herbage yield was obtained from $75 \%$ Buckwheat- $25 \%$ Soybean application $(3100 \mathrm{~kg} / \mathrm{da})$ at $2 \mathrm{nd}$ harvest time. When the average of hay yield was examined, the results were similar to herbage yield. When ADF and NDF were examined, the highest values were seen at the 2 nd harvest. When the crude protein ratios were examined, it was found that they decreased at the 2 nd harvesting time and the highest value was determined at $100 \%$ soybean application at the 1 st harvesting time $(21.08 \%)$. When Digestible Dry Matter (DDM) and Relative Feed Value (RFV) were examined, the highest values were determined in $100 \%$ Soybean applications at first harvest time and when the mixture applications were examined, the highest values were determined to be $75 \%$ Buckwheat - $25 \%$ Soybean application. As a result of the study, it was determined that the yields obtained at the 2 nd harvest time were higher but the forage quality decreased. When the mixtures were examined, it was determined that the mixture having the highest roughage value was $75 \%$ buckwheat $+25 \%$ soybean application. In this study, the buckwheat which have short vegetation and good quality and the soybean, which is infront of with high quality, mixtures were examined. It has also been found that these mixtures may be important for obtaining high-quality forage in the short and intermediate periods.

Türk Tarım - Gıda Bilim ve Teknoloji Dergisi, 5(13): 1732-1736, 2017

\section{Organik Tarım Koşullarında Karabuğday-Soya Karışımlarının Verim ve Kalite Özellikleri}

\section{A K A L E B İ L G İ S İ}

\section{AraștırmaMmakalesi}

Geliş 12 Eylül 2017

Kabul 30 Kasim 2017

\section{Anahtar Kelimeler:}

Karabuğday

Soya

Karışım

Ham protein

ADF

$\mathrm{NDF}$

*Sorumlu Yazar:

E-mail: mustafa.surmen@adu.edu.tr

\section{Ö Z E T}

$\mathrm{Bu}$ çalışma Aydın ekolojik koşullarında yetiştirilebilecek alternatif kaliteli kaba yem kaynaklarını belirlemek amacıyla 2014 yılı yaz üretim sezonunda yürütülmüştür. Araştırmada karabuğday ve soya yalın ve 3 farklı karışım (\%25 Karabuğday - \%75 Soya, \%50 Karabuğday - \%50 Soya, \%75 Karabuğday - \%25 Soya,) ve 2 farklı hasat zamanının (\%50-\%100 çiçeklenme/karabuğday) verim ve kalite özelliklerine etkileri incelenmiştir. Ölçüm sonuçlarına göre en yüksek yaş ot verimi ortalaması ikinci hasatta \%75 Karabuğday - \%25 Soya uygulamasında $(3100 \mathrm{~kg} / \mathrm{da})$ elde edilmiştir. Kuru ot verim ortalamaları incelendiğinde yaş ot verimine benzer sonuçlar ADF ve NDF incelendiğinde en yüksek değerler ikinci hasatlarda, ham protein oranları incelendiğinde ikinci hasatlarda düşüşler görülmüş, en yüksek değer ise ilk hasatta \%100Soya uygulamasında $(\% 21,08)$ tespit edilmiştir. Sindirilebilir Kuru Madde (SKM) ve Nispi Yem Değeri (NYD) incelendiğinde en yüksek değerler ilk hasatta \%100Soya uygulamalarında tespit edilmiş olup karışım uygulamaları incelendiğinde en yüksek değerlerin \%75 Karabuğday - \%25 Soya uygulamasından elde edildiği gözlenmiştir. Çalışmanın sonucunda ikinci hasatta elde edilen verimlerin daha yüksek ancak yem kalitesinde düşüşler tespit edilmiştir. Karışımlar incelendiğinde ise en iyi uygulamanın \%75 Karabuğday $+\% 25$ Soya olduğu tespit edilmiştir. Vejetasyon süresinin kısa olması ve kalite özellikleriyle gündemde olan karabuğdayın, kalite özellikleriyle ön planda olan soya ile yaptığı karışımlar bu çalışmada incelenmiştir. Kısa sürede ve ara dönemlerde ekstra kaliteli kaba yem kaynağı elde etmeye yönelik olarak bu karışımların önemli olabileceği tespit edilmiştir. 


\section{Introduction}

Forage crops are known to have a positive influence on the physical and chemical properties of the soil and on the yield and quality of the cultivated plants following it, as well as providing the fodder which constitutes one of the most important inputs of animal production. In our country, it is determined that lack of total high quality roughage of 2015 is 30.2 million tons. Alternative forage sources production (cereals, plant residues, industrial wastes and buckwheat etc.) are needed to improve in order to close this deficit.

Buckwheat is an annual plant of the family Polyganeaceae and has no connection with grains (Acar et al. 2009). Buckwheat has been used as feed for cattle, pigs and chickens historically (Myers and Meinke, 1994). The grain is higher in amino acids like lysine, which is deficient in other grains, but overall it has lower feed value than wheat, oats, barley, rye, or corn (Oplinger et al., 1989). Buckwheat grows in the shortest time period of all cover crops (Bjorkman and Shail, 2010). During its growth period produces about 2 to 3 tons of biomass per acre (Clark, 2007; Pavek, 2014). The buckwheat can also be grown as a summer forage crop with cowpea, grain sorghum and soybean. It has the characteristics of being a forage source during periods when flowering in 5-6 weeks, consumed lovingly by animals, and in the case of coarse forage scarce (Anonymous, 2017a,b.).

Soybean has potential for use as an alternative forage crop, however, little is known about the effects of cultural practices on forage yield and quality (Hintz et al. 1992). There has been a growing interest in adopting soybean silage for animal feeding in several countries such as United States, United Kingdom, Costa Rica, Vietnam, China and also Brazil (Rigueira et al., 2015). It is observed that soybeans are well adapted in our country and especially in Aegean and Mediterranean region (Acikgoz et al. 2009; Bilgili et al. 2005; Tans1, 1987).

This study was conducted to investigate the yield and quality of mixtures of buckwheat and soybean, which are alternative forage plants that have begun to increase in recent years. It is thought that the mixture of soybean and buckwheat, which is considered as a source of protein in this subject, where there is not much work to be done, is a forage for a short period of time in the time of roughage.

\section{Material and Method}

The experiment was carried out in three replications with 3 different buckwheat (Fagopyrum esculentum Moench).-soybean (Glycine $\max$ L.) mixtures $(25 \%$ Buckwheat- $75 \%$ Soybean, 50\% Buckwheat- $50 \%$ Soybean, $75 \%$ Buckwheat - 25\% Soybean) and 2 species using buckwheat and soybean as material in Aydin ecological conditions. Although the experiment area has a low organic matter content, it is found in soil analyzes that it is sufficient for mineral matter. In order to provide organic farming conditions, no chemical fertilization and spraying were done. Harvest was carried out at 2 different times. Flowering times of $50 \%$ and $100 \%$ of the buckwheat, in which flowering occurs earlier for harvests, were preferred. Herbage yield $(\mathrm{kg} / \mathrm{da})$ was measured after harvesting and hay yield $(\mathrm{kg} / \mathrm{da})$ was measured by fan drying at $70^{\circ} \mathrm{C}$ for 48 hours until the weight was fixed (Albayrak et.al., 2006). The crude protein (\%) of the samples taken from the experiment were according to the method of AOAC (2003); NDF and ADF contents (\%) Van Soest et al. (1991). The ADL contents of the samples were determined as a result of the determination of the ADF-specimens in a $72 \% \mathrm{H}_{2} \mathrm{SO}_{4}$ solution for 3 hours. The crude protein yield $(\mathrm{kg} / \mathrm{da})$, digestible dry matter (DDM\%) and relative feed value (RFV) were calculated by the obtained data. The following procedures were used to calculate the relative feed value (Horrocks and Vallentine, 1999).

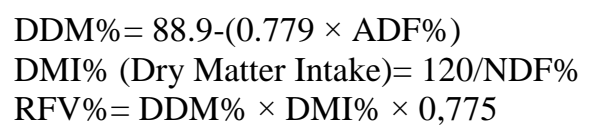

In order to compare the results obtained from the study, variance analysis was applied according to randomized blocks trial design with the help of MSTAT$\mathrm{C}$ statistical package program. LSD multiple comparison test was used in comparison of the averages.

\section{Results and Discussion}

There are no studies on mixtures of buckwheat and soybean, and information on the values of buckwheat and soybean plants are limited. The best application rate (2791.7 kg/da) was found to be $75 \%$ buckwheat - $25 \%$ soybean mixture in terms of yield of herbage yield and no statistical difference was found between harvest time averages. When the interaction between harvesting time and application was examined, it was determined that the values changed between 1516.66-3100 kg/da and the highest herbage yield average was observed in $25 \%$ buckwheat - $75 \%$ soybean mixture application at $100 \%$ flowering time. According to the results of the experiment, it was observed that buckwheat herbage yield was similar to that of Kara (2014) and soybean herbage yield was similar to Erdoğdu (2004). When the hay yield were examined, it was determined that the highest application average $(987.61 \mathrm{~kg} / \mathrm{da})$ was in the mixture of $75 \%$ buckwheat and $25 \%$ soybean mixture and the highest harvesting time average was $756.66 \mathrm{~kg} / \mathrm{da}$ at $100 \%$ flowering time. When the interaction between the harvesting time and the applications was examined, it was determined that the values changed between 481.26 $1109.4 \mathrm{~kg} / \mathrm{da}$; the highest hay yield was determined at $100 \%$ flowering time at $75 \%$ buckwheat $-25 \%$ soybean application (Table 1) According to the results, buckwheat hay yield similar to Keleş et al. (2012), El Bassam (2010) and Kara (2014). Result from soybean dry forage yield is similar to Asseed et al. (2000) and lower than Açıkgöz et al. (2013) and Erdogdu (2004). Kara (2014) stated that yield changes depending on environmental conditions, breeding techniques, harvest time. It is thought that these are the reasons why the results obtained from the experiment differ from some studies. 
Table 1 Averages and grouping of green forage yield, hay yield, NDF, ADF, ADL, crude protein ratio, crude protein yield, digestible dry matter and relative feed value of the buckwheat-soybean mixture applications harvested at two different times in the experiment

\begin{tabular}{|c|c|c|c|}
\hline \multirow{2}{*}{ Applications } & \multicolumn{3}{|c|}{ Herbage Yield (kg/da) } \\
\hline & $\% 50$ Flowering. & $\% 100$ Flowering. & Average \\
\hline$\% 100 \mathrm{BW}$ & 1683.33 & 1666.66 & $1675.0 \mathrm{D}$ \\
\hline$\% 75 \mathrm{BW}+\% 25 \mathrm{~S}$ & 3050.00 & 2533.33 & $2791.7 \mathrm{~A}$ \\
\hline$\% 50 \mathrm{BW}+\% 50 \mathrm{~S}$ & 1433.33 & 2416.66 & $1925.0 \mathrm{CD}$ \\
\hline$\% 25 \mathrm{BW}+\% 75 \mathrm{~S}$ & 1850.00 & 3100.00 & $2475.0 \mathrm{~B}$ \\
\hline$\% 100 \mathrm{~S}$ & 2516.66 & 1516.66 & $2016.7 \mathrm{C}$ \\
\hline \multirow[t]{2}{*}{ Aveeage } & 2106.67 & 2246.67 & $\mathrm{CV}(\%): 10.82$ \\
\hline & \multicolumn{3}{|c|}{ Hay Yield $(\mathrm{kg} / \mathrm{da})$} \\
\hline$\% 100 \mathrm{BW}$ & 549.75 & 508.52 & $529.14 \mathrm{D}$ \\
\hline$\% 75 \mathrm{BW}+\% 25 \mathrm{~S}$ & 865.82 & 1109.40 & $987.61 \mathrm{~A}$ \\
\hline$\% 50 \mathrm{BW}+\% 50 \mathrm{~S}$ & 554.91 & 546.63 & $550.77 \mathrm{D}$ \\
\hline$\% 25 \mathrm{BW}+\% 75 \mathrm{~S}$ & 481.26 & 953.50 & $717.38 \mathrm{~B}$ \\
\hline$\% 100 \mathrm{~S}$ & 593.79 & 665.24 & $629.52 \mathrm{C}$ \\
\hline \multirow[t]{2}{*}{ Aveeage } & $609.11 \mathrm{~B}$ & $756.66 \mathrm{~A}$ & $\mathrm{CV}(\%): 7.44$ \\
\hline & \multicolumn{3}{|c|}{$\operatorname{NDF}(\%)$} \\
\hline$\% 100 \mathrm{BW}$ & 31.83 & 40.66 & $36.24 \mathrm{C}$ \\
\hline$\% 75 \mathrm{BW}+\% 25 \mathrm{~S}$ & 32.40 & 43.78 & $38.09 \mathrm{~B}$ \\
\hline$\% 50 \mathrm{BW}+\% 50 \mathrm{~S}$ & 40.36 & 40.68 & $40.52 \mathrm{~A}$ \\
\hline$\% 25 \mathrm{BW}+\% 75 \mathrm{~S}$ & 32.39 & 42.01 & $37.20 \mathrm{BC}$ \\
\hline$\% 100 \mathrm{~S}$ & 30.45 & 38.19 & $34.32 \mathrm{D}$ \\
\hline \multirow[t]{2}{*}{ Aveeage } & $33.48 \mathrm{~B}$ & $41.06 \mathrm{~A}$ & $\mathrm{CV}(\%): 3.65$ \\
\hline & \multicolumn{3}{|c|}{$\operatorname{ADF}(\%)$} \\
\hline$\% 100 \mathrm{BW}$ & 28.04 & 35.82 & $31.93 \mathrm{C}$ \\
\hline$\% 75 \mathrm{BW}+\% 25 \mathrm{~S}$ & 28.76 & 38.11 & $33.44 \mathrm{AB}$ \\
\hline$\% 50 \mathrm{BW}+\% 50 \mathrm{~S}$ & 33.97 & 34.94 & $34.45 \mathrm{~A}$ \\
\hline$\% 25 \mathrm{BW}+\% 75 \mathrm{~S}$ & 28.86 & 36.63 & $32.74 \mathrm{BC}$ \\
\hline$\% 100 \mathrm{~S}$ & 25.94 & 31.32 & $28.63 \mathrm{D}$ \\
\hline \multirow[t]{2}{*}{ Aveeage } & $29.11 \mathrm{~B}$ & $35.36 \mathrm{~A}$ & $\mathrm{CV}(\%): 2.76$ \\
\hline & \multicolumn{3}{|c|}{ ADL $(\%)$} \\
\hline$\% 100 \mathrm{BW}$ & 2.40 & 2.92 & $2.66 \mathrm{~B}$ \\
\hline$\% 75 \mathrm{BW}+\% 25 \mathrm{~S}$ & 2.35 & 2.55 & $2.45 \mathrm{~B}$ \\
\hline$\% 50 \mathrm{BW}+\% 50 \mathrm{~S}$ & 3.56 & 3.10 & $3.33 \mathrm{~A}$ \\
\hline$\% 25 \mathrm{BW}+\% 75 \mathrm{~S}$ & 2.62 & 2.61 & $2.62 \mathrm{~B}$ \\
\hline$\% 100 \mathrm{~S}$ & 3.23 & 3.59 & $3.41 \mathrm{~A}$ \\
\hline \multirow[t]{2}{*}{ Average } & 2.83 & 2.95 & $\mathrm{CV}(\%): 18.40$ \\
\hline & \multicolumn{3}{|c|}{ Crude Protein Ratio (\%) } \\
\hline$\% 100 \mathrm{BW}$ & 15.89 & 13.56 & $14.72 \mathrm{C}$ \\
\hline$\% 75 \mathrm{BW}+\% 25 \mathrm{~S}$ & 18.63 & 14.80 & $16.71 \mathrm{~B}$ \\
\hline$\% 50 \mathrm{BW}+\% 50 \mathrm{~S}$ & 16.45 & 16.20 & $16.33 \mathrm{~B}$ \\
\hline$\% 25 \mathrm{BW}+\% 75 \mathrm{~S}$ & 18.29 & 14.18 & $16.23 \mathrm{~B}$ \\
\hline$\% 100 \mathrm{~S}$ & 21.08 & 19.74 & $20.41 \mathrm{~A}$ \\
\hline \multirow[t]{2}{*}{ Average } & $18.07 \mathrm{~A}$ & $15.70 \mathrm{~B}$ & $\mathrm{CV}(\%): 6.66$ \\
\hline & \multicolumn{3}{|c|}{ Crude Protein Yield (kg/da) } \\
\hline$\% 100 \mathrm{BW}$ & 87.19 & 68.93 & $78.06 \mathrm{C}$ \\
\hline$\% 75 \mathrm{BW}+\% 25 \mathrm{~S}$ & 162.29 & 164.18 & $163.24 \mathrm{~A}$ \\
\hline$\% 50 \mathrm{BW}+\% 50 \mathrm{~S}$ & 91.31 & 88.57 & $89.94 \mathrm{C}$ \\
\hline$\% 25 \mathrm{BW}+\% 75 \mathrm{~S}$ & 88.70 & 135.78 & $112.24 \mathrm{~B}$ \\
\hline$\% 100 \mathrm{~S}$ & 125.06 & 131.33 & $128.20 \mathrm{~B}$ \\
\hline \multirow[t]{2}{*}{ Average } & 110.91 & 117.76 & $\mathrm{CV}(\%): 12.50$ \\
\hline & & stible Dry Matter & \\
\hline$\% 100 \mathrm{BW}$ & 67.05 & 60.99 & $64.02 \mathrm{~B}$ \\
\hline$\% 75 \mathrm{BW}+\% 25 \mathrm{~S}$ & 66.49 & 59.20 & $62.85 \mathrm{CD}$ \\
\hline$\% 50 \mathrm{BW}+\% 50 \mathrm{~S}$ & 62.43 & 61.68 & $62.05 \mathrm{D}$ \\
\hline$\% 25 \mathrm{BW}+\% 75 \mathrm{~S}$ & 66.41 & 60.36 & $63.38 \mathrm{BC}$ \\
\hline$\% 100 \mathrm{~S}$ & 68.68 & 64.49 & $66.59 \mathrm{~A}$ \\
\hline Average & $66.21 \mathrm{~A}$ & $61.34 \mathrm{~B}$ & $\mathrm{CV}(\%): 1.08$ \\
\hline & & elative Feed Value & \\
\hline$\% 100 \mathrm{BW}$ & 196.22 & 139.75 & $167.99 \mathrm{~B}$ \\
\hline$\% 75 \mathrm{BW}+\% 25 \mathrm{~S}$ & 191.02 & 125.80 & $158.41 \mathrm{C}$ \\
\hline$\% 50 \mathrm{BW}+\% 50 \mathrm{~S}$ & 143.91 & 141.00 & $142.46 \mathrm{D}$ \\
\hline$\% 25 \mathrm{BW}+\% 75 \mathrm{~S}$ & 191.26 & 133.82 & $162.54 \mathrm{BC}$ \\
\hline$\% 100 \mathrm{~S}$ & 209.78 & 157.14 & $183.46 \mathrm{~A}$ \\
\hline Average & $139.50 \mathrm{~B}$ & $186.44 \mathrm{~A}$ & $\mathrm{CV}(\%): 4.50$ \\
\hline
\end{tabular}


In late NDF\% (Neutral Detergent Fiber) average, the amount of fiber increased. As NDF\% increases, forage quality and digestibility decrease. The lowest NDF\% $(34.32 \%)$ according to application averages was seen in $100 \%$ soybean application. The highest NDF\% (40.52\%) was detected in $50 \%$ buckwheat - 50\% soybean application. The lowest harvesting time average (33.48\%) was determined at $50 \%$ flowering time. When the interaction between the harvesting time and the application was examined, it was found that the values were changed between $30.45-43.78 \%$ and the lowest average application was found to be $100 \%$ soybean harvested in $50 \%$ flowering period (Table 1). Conclusions are similar to Keleş et al. (2012) for buckwheat, Açıkgöz et al. (2013) and Rigueira et al. (2015). ADF\% (Acid Detergent Fiber) averages showed similar results to the NDF\% averages and the lowest mean $(28.63 \%)$ was again detected in $100 \%$ soybean application. The values according to application-harvest time interaction varied between $25.94 \%$ and $34.11 \%$. The lowest ADF\% $(25.94 \%)$ was also detected in $100 \%$ soybean application in 50\% flowering period. Conclusions are similar to Keleş et al. (2012) for buckwheat, Açıkgöz et al. (2013) and Rigueira et al. (2015) for the soybean. There was no statistical difference between the average ADL\% (Acid Detergent Lignin) and harvesting times, with the lowest application average being $2.66 \%$ in $100 \%$ buckwheat application. Values for harvest time-application interactions ranged from 2.4 to $3.59 \%$. The lowest value was determined during the application of $100 \%$ buckwheat during the flowering period of $50 \%$ (Table 1). There is not much work in terms of ADL\% and Keleş et al. (2012) stated that information on the chemical composition of buckwheat was limited.

The highest application rate in terms of crude protein ratio was $20.41 \%$ in $100 \%$ soybean application. A decrease in the crude protein ratio at late harvest was determined, with values ranging from $13.56 \%$ to $21.08 \%$. Conclusions for pure buckwheat are similar to Keles et al. (2012), Campbell (1997), Björksman and Chase (2013), showing higher than Kara (2014). Results from pure soybean are similar to Hintz et al. (1992), Asseed et al. (2000), and higher than Rigueira et al. (2015), Erdoğdu (2004), Açıkgöz et al. (2013). According to crude protein yield averages, the highest application averages were $163.24 \mathrm{~kg} \mathrm{/} \mathrm{da} \mathrm{with} 75 \%$ buckwheat - $25 \%$ soybean application and no statistical difference was observed between harvest times. The values obtained from the experiment varied between $68.93-164.18 \mathrm{~kg} / \mathrm{da}$ and the highest value was obtained from application of $75 \%$ buckwheat - $25 \%$ soybean at $100 \%$ flowering time. In terms of digestible dry matter averages, the highest application was determined with $66.59 \%$ in $100 \%$ soybean application and the highest harvest time application was obtained from $66.21 \%$ to $50 \%$ flowering period. The mean values in the experiment ranged from $59.20 \%$ to $68.68 \%$ and the highest digestible dry matter averages were determined during $100 \%$ soybean application in $50 \%$ flowering period. When the average relative feed value was examined, the highest average application rate was 183.46 in $100 \%$ soybean application. It was determined that the highest value of mixture applications was $162.54 \%$ with $25 \%$ buckwheat $-75 \%$ soybean application. The highest value (186.44) according to the average of harvest time was observed in $100 \%$ flowering period. Values ranged from 125.8 to 209.78 and the highest relative feed value was obtained from $100 \%$ soy application in $50 \%$ flowering period (Table 1). The results are higher than Kara (2014) for lean buckwheat, and similar to Açıkgöz et al. (2013) for the lean soybeans.

\section{Conclusions}

Although the buckwheat has been used since ancient times, its production has increased with the recent use of it for various purposes. Buckwheat, which comes to the fore with its early maturation, grain-like chemical composition and nutrition. In the study, soybean which is the other plant which is cultivated in mixture, has high quality protein. In this experiment, in which the yield and quality of different mixtures of these two plants, which are increasing in production, were examined, it was seen that yield was high but quality was low especially in $100 \%$ flowering compared to 2 different time. In terms of quality, when the applications were examined, it was determined that the pure soybean was the front line; in terms of yield, and the highest values were determined as $75 \%$ buckwheat and $25 \%$ soybean mixtures. It was found that the highest value of relative feed value was in pure soybean and pure buckwheat while the highest relative feed value was found in mixture of $75 \%$ soybean $+25 \%$ buckwheat. It is thought that this and similar studies should continue because there is not much work on this subject even though they are quality forage source.

\section{References}

Acar R. 2009. Cultivation of buckwheat. Konya Comm. Exch. J., 31:30-37.

Açıkgöz E, Sincik M, Karasu A, Töngel O, Wietgrefe G, Bilgili U, Oz M, Albayrak S, Turan ZM, Göksoy AT. 2009. Forage soybean production for seed in mediterranean environments. Field Crop. Res., 110: 213-218.

Açıkgöz E, Sincik, M, Wietgrefe G, Sürmen M, Çeçen S, Yavuz T, Erdurmuş C, Göksoy AT. 2013. Dry matter accumulation and forage quality characteristics of different soybean genotypes. Turk J Agric For., 37: 22-32.

Albayrak S, Mut Z, Töngel Ö. 2006. Hay and grain yields with some agricultural traits of Triticale (XTriticosecale Wittmack) lines. SDU J. Fac. of Agric., 1(1):13-21.

Anonymous. 2017a. Buckwheat: Easy Summer Forage. https://www.qdma.com/buckwheat-easy-summer-forage/ accesed at 25.08.2017.

Anonymous. 2017b. Buckwheat for Forage. http://www.hort.cornell.edu/bjorkman/lab/buck/guide/forage .php accessed at 25.08.2017.

Assaeed AM, Saiady MY, El-Shawaf II. 2000. Yield and quality of soybean forage as affected by harvesting time and cultivar. Res. Bult., No (89), Agric. Res. Center, King Saud Univ., (5-13).

AOAC. 2003. Official methods of analysis of AOAC International. 17th Ed. 2nd Rev. Gaithersburg, MD, USA, Association of Analytical Communities.

Björkman T, Shail JW. 2010. Cover Crop Fact Sheet Series: Buckwheat. Available at http://covercrops.cals.cornell.edu /pdf/buckwheatcc.pdf (accessed 7 Aug 2014). Cornell University Cooperative Extension, Ithaca, NY. 
Björkman. T, Chase L. 2013. Buckwheat for forage. http://www.hort.cornell.edu/bjorkman/lab/buck/guide/forage .php accessed at 22.10.2013.

Bilgili U, Sincik M, Göksoy AT, Turan ZM, Açıkgöz E. 2005. Forage and grain yield performances of soybean lines. Centr. Europ. Agricult., 6: 397-402.

Campbell CG. 1997. Buckwheat (Fagopyrum esculentum Moench.) promoting the conservation and the use of underutilized and neglected crops. 19. IBPGR, Rome. Italy.

Clark A. (ed.) 2007. Managing Cover Crops Profitably. 3rd ed. Sustainable Agriculture Research and Education (SARE) Handbook Series, bk 9. Sustainable Agriculture Research and Education, College Park, MD.

El Bassam N. 2010. Pseudocereals: Amaranthus, Buckwheat, Quinoa. Handbook of Bionergy Crops, London, UK. Earthscan.

Erdoğdu İ. 2004. The effect of different seedıng rates of intercropped cornand soybean on some plant characteristics and forage yield. Ankara University Institute of Science and Technology (PhD Thesis).

Hintz RW, Albrecht KA, Oplinger ES. 1992. Yield and quality of soybean forage as affected by cultivar and management practices. Agron.J., 84:795-798.

Horrocks RD, Vallentine JF. 1999. Harvested Forages. San Diego, California, USA. Academic Press, 3-87,

Kara N, Yüksel O, 2014. Can we use buckwheat as an animal feed? Tur. J. of Agr. and Nat. Sci., 1(3): 295-300.

Keleş G, Ateş S, Güneş A, Halıcı I, 2012. Nutritive value and fermentation characteristics of buckwheat silage ensiled with chemical or biological additives. Selç. J. of Agri. and Food Sci., 26 (4): 33-36.
Myers RL, Meinke LJ. 1994. Buckwheat: A multi-purpose, short-season alternative. University of Missouri Extension Bulletin G4306. University of Missouri, Columbia, MO. Available at: http://extension.missouri.edu/publications/ DisplayPub.aspx?P=G4306 accessed 04. 09.2014.

Oplinger ES, Oelke EA, Brinkman MA, Kelling KA. 1989. Alternative Field Crops Manual: Buckwheat. Available at http://www.hort.purdue.edu/newcrop/afcm/buckwheat.html accessed 26.08.2017.

Özkan U, Demirbăg NS. 2016. Status Quo and Quality Roughage Resources in Turkey. Tur. J. of Sci. Rev., 9(1): 23-27.

Pavek PLS. 2014. Evaluation of Cover Crops and Plantings Dates for Dryland Eastern Washington Rotations. Plant Materials Technical Note No. 25. United States Department of Agriculture - Natural Resources Conservation Service. Spokane, WA.

Rigueira JPS, Pereira OG, Filho SCV, Ribeiro KG, Garcia R, Cezario AS, 2015. Soybean silage in the diet for beef cattle. Acta Scientiarum. Anim. Sci., 37(1) 61-65.

Tans1 V. 1987. Investigations on the effect of grain and gross feed efficiency on the cultivation of corn and soybean as a second crop in different sowing systems in Çukurova region. Ç.Ü. Graduate School of Natural and Applied Sciences Field Crops (PhD Thesis).

Van-Soest PJ, Robertson JB, Lewis BA, 1991. Method for Dietary Fiber, Neutral Detergent Fiber, and Nostarch Polysaccharides in Relation to Animal Nutrition. J. Dairy Sci., 74:3583-3597. 